\title{
When an Artist works for Scientists: On Beulah Mitchell Clute and Her Bookplates for Scientists of the University of California at Berkeley
}

\author{
Quand une artiste œuvre pour la Science : Les ex-libris de Beulah \\ Mitchell Clute à Berkeley - Université de Californie
}

\author{
John R. Dolan ${ }^{1}$ \\ ${ }^{1}$ Sorbonne Université CNRS, Laboratoire d'Océanographie de Villefranche-sur-Mer, Station Zoologique, 06230 \\ Villefranche-sur-Mer, France, john.dolan@imev-mer.fr
}

\begin{abstract}
Beulah Mitchell Clute (1873-1958) was a talented artist who specialized in the design of bookplates. She was well known in her time, from her days as an art student, and today is still recognized as a very talented designer. Among her most famous creations are 3 bookplates for scientists of the faculty of the University of California in the early 1900's. Here the story of Beulah Clute will be told, the range of her work demonstrated, and her bookplates for three very successful University of California scientists will be shown in the context of her many bookplates for others. Clute's bookplates were usually decorative and mainly served to show ownership. In contrast, the bookplates for the scientists were dominated by depictions of items and scenes related to their professional careers. The bookplates of the scientists did not simply show ownership. They prominently showcased their achievements and lives. The hypothesis that the scientists, each of whom who rose to chair their respective departments, indulged their vanities with their bookplates, is put forward, in line with observations that high ego personalities are successful in the sciences.
\end{abstract}

KEYWORDS. scientific illustration, narcissism, Ex-Libris, L. Beulah Mitchell, Leuschner, Kofoid, Essig.

\section{Introduction}

Bookplates (or Ex-Libris) have existed for hundreds of years. The first known are said to date back to the late-1400's when movable type was introduced to print books. Some very early bookplates were designed by artists still well-known today such as Albrecht Dürer. (Clute 1924). Then as today, the primary purpose of a bookplate is to mark ownership and induce the return of a borrowed book as charmingly put by Bowdoin in 1917:

"The book-plates of to-day serve the same purpose as when they were first produced to confound the book borrower who failed to return the volume he had borrowed. Nestling unobtrusively in its proper place in the book when closed, a bookplate nevertheless stares accusingly at the man who opens it but who withholds it from its proper place in the owner's library".

Obviously, denoting ownership is not the only purpose of a bookplate as one can simply write one's name in the inside cover. A bookplate is a decorative means of marking ownership and often contained elements that reflected the personality, tastes and interests of the book owner. Having a bookplate made was not a trivial expense. American bookplate artists in the early 1900's, the main period of focus in this article, charged from $\$ 5$ to $\$ 600$, with an average of about $\$ 50$ (see Fowler 1921), equivalent to nearly $\$ 1000$ today. Consequently, bookplates were generally commissioned by the relatively wealthy. As objects of interest and value, in and of themselves, bookplates have been collected since the 1820's. Many museums hold bookplates in their collections of prints (e.g., Metropolitan Museum of New York, Fine Arts Museum of San Francisco). 
Here the story will be told of one bookplate artist, Beulah Mitchell Clute, and her bookplates. The backstory is that one of her bookplates was that of Charles Atwood Kofoid (1865-1947), a zoologist at the University of California at Berkeley. He was a pioneer in the study of a group of microorganisms of the marine plankton, tintinnid ciliates, which have been the focus of my professional career. I knew of Kofoid's bookplate because it featured many of the microorganisms of the plankton with which I am quite familiar. Recently, I acquired a book with Kofoid's bookplate and this prompted me to set out to find more about Kofoid's bookplate, its creator, and bookplates in general. I quickly discovered that Kofoid's bookplate is actually well known (e.g., it suffices to Google "Kofoid Bookplate") and has been written about repeatedly (i.e., Jackson 2003; Anon. 2011; Sanders, 2001) but I found little information readily available on its creator other than a name, Beulah Mitchell Clute. Luckily, the name Beulah is relatively rare and the literature on bookplates is considerable. The account given here of her life and work, albeit incomplete, was assembled by searching through a large variety of sources (newspaper archives, bookplate society journals, books on bookplates, full text searches of digitized content in Hathi Trust Digital Library, and the Biodiversity Library) and aided greatly by advice and information provided by Anthony Pincott of the Bookplate Society (London).

The picture emerged of a talented artist who created bookplates in a remarkably wide range of styles. However among all her bookplates, 3 stand out. They were for scientists of the University of California: the astronomer Armin Otto Leuschner, the entomologist Edward Oliver Essig, and the zoologist Charles Atwood Kofoid. In comparison to all of the other bookplates of Beulah Clute I found, they appeared particularly celebratory of the men's accomplishments. Here the differences will be shown and the hypothesis put forward that the scientists, each remarkably successful, were likely high-ego individuals, recognized today as a personality type typical of high-performing scientists.

\section{Biographical Sketch of Beulah Mitchell Clute}

The following story of the life of Beulah Mitchell Clute is based largely on information found in the autobiographical books by her grandmother (Seeley 1901), and her sister in-law (Mitchell 1953) and also a book on Park Ridge, the community in which the Clutes lived from 1903 to 1914 (Barnes 2010).

Beulah Clute was born in 1873 as Lydia Beulah Mitchell. The name Beulah was after her maternal grandmother Beulah McClellan Seeley. She always went by Beulah or L. Beulah and she was the first of 7 children. Her father was a medical doctor and the family lived in series of small towns in Illinois. At the age of 19 she left the family home then in Decatur, Illinois to study art at the New York Art Students' League. After three years, in 1895, she left New York to continue her studies in Chicago, at the Chicago Art Institute. In Chicago she joined her brother Clair and sister Eunice, who were then both students at the University of Chicago.

1899 was an eventful year for the young Mitchell siblings. Beulah became engaged to Walter Clute, a young painter, journalist, and instructor at the Chicago Art Institute. Eunice married Norman Lehmer who had just completed his Ph.D., and then they moved to Berkeley, California, where her husband joined the faculty of the Department of Mathematics at the University of California. Clair Mitchell defended his Ph.D. in Economics. He would go on to a very notable career in economics (detailed in Mitchell 1953).

In late 1900, Beulah and Walter married. As Mrs. Beulah Clute, she was in the Jury of Selection (the only woman with 3 men) for 1901 Exhibition of the Art Student's League of Chicago (Anon. 1901a). By 1903 they settled in Park Ridge, a suburb of Chicago, joining a small group of artists and artisans active in the Arts and Crafts Movement of the early 1900's. Park Ridge became known as home to the 'Art Colony' of Chicago. Walter Clute continued to teach at the Art Institute of Chicago. 
In 1904 Marjorie Clute was born to the young couple. We know that Beulah Clute continued with some artistic activity as she exhibited a water-color and 12 bookplate designs in the 1907 Exhibition of the Art Institute of Chicago "Water-colors, Pastels and Miniatures by American Artists" (Anon. 1907). In the 1911 exhibition Clute again exhibited 12 bookplates (Anon. 1911a). When Marjorie reached school age in 1910, Beulah Clute teamed up with another artist, Dulah Evans Krehbiel, to start a small business, "The Colony Craft" which produced postcards, greeting cards and bookplates. In Park Ridge they were successful financially, and socially very active, at the center of the artist community. However, by early 1914 it became obvious that Walter Clute's health problems were worsening (likely tuberculosis) and might be improved if the family moved to a warmer climate. In December of 1914 they moved to Cucamonga in southern California, near Los Angeles. Sadly, the move was for naught. On February 14 of 1915 Walter Clute died of a stroke leaving Beulah, at age 38 , a widow with the 11 year-old Marjorie.

Following the death of Walter Clute, Beulah and Marjorie Clute moved to Berkeley where her sister Eunice and brother-in-law Norman Lehmer lived. At that time, Norman Lehmer was an Associate Professor in the Department of Mathematics at the University of California. Beulah worked as an illustrator of books and bookplate designer in Berkeley, first independently, and then as the designer of the Three Redwoods Studio in Berkeley. She became known as an authority on bookplates. Beulah Clute lectured on bookplates at the library of the University of California and contributed an article on bookplates to the academic journal, the University of California Chronicle (Clute 1924). Her last documented work was as the illustrator for her brother-in-law Norman Lehmer's book " Just the Two of Us: Verses for Boys and Girls " in published in 1943; at that time she was 70 years old. Beulah Mitchell Clute died in 1958 at age 85.

\section{The Art of L. Beulah Mitchell as a Student}

I found no traces of her student days in New York. However, as a student of art in Chicago, Beulah Mitchell produced a wide range of works (fig. 1), many of which received a good deal of attention. Especially remarked upon in the Chicago newspapers were her cover illustration for a very popular cookbook published by the Chicago Record Newspaper (Anon. 1897a), the catalogue covers of the annual exhibition of the Chicago Students' Art League for the 1897 (Anon. 1897b) and 1898 (Baker 1899) shows, and for an art journal, Pickwick Magazine (Anon. 1898a). Her sketch work was also featured in an article on the class in illustration of the Chicago Art Institute (Anon 1898b). She was awarded the first prize in the 1897 exhibition for a black and white sketch (Anon. 1897c). In a newspaper article on the 1989 exhibition she was noted as one of the best undergraduates of the Chicago Art Institute (Anon. 1898c). Beulah Mitchell was also quite active in the organizational aspects of Art Students' League, serving as President in 1898-1899 (Anon. 1899). 

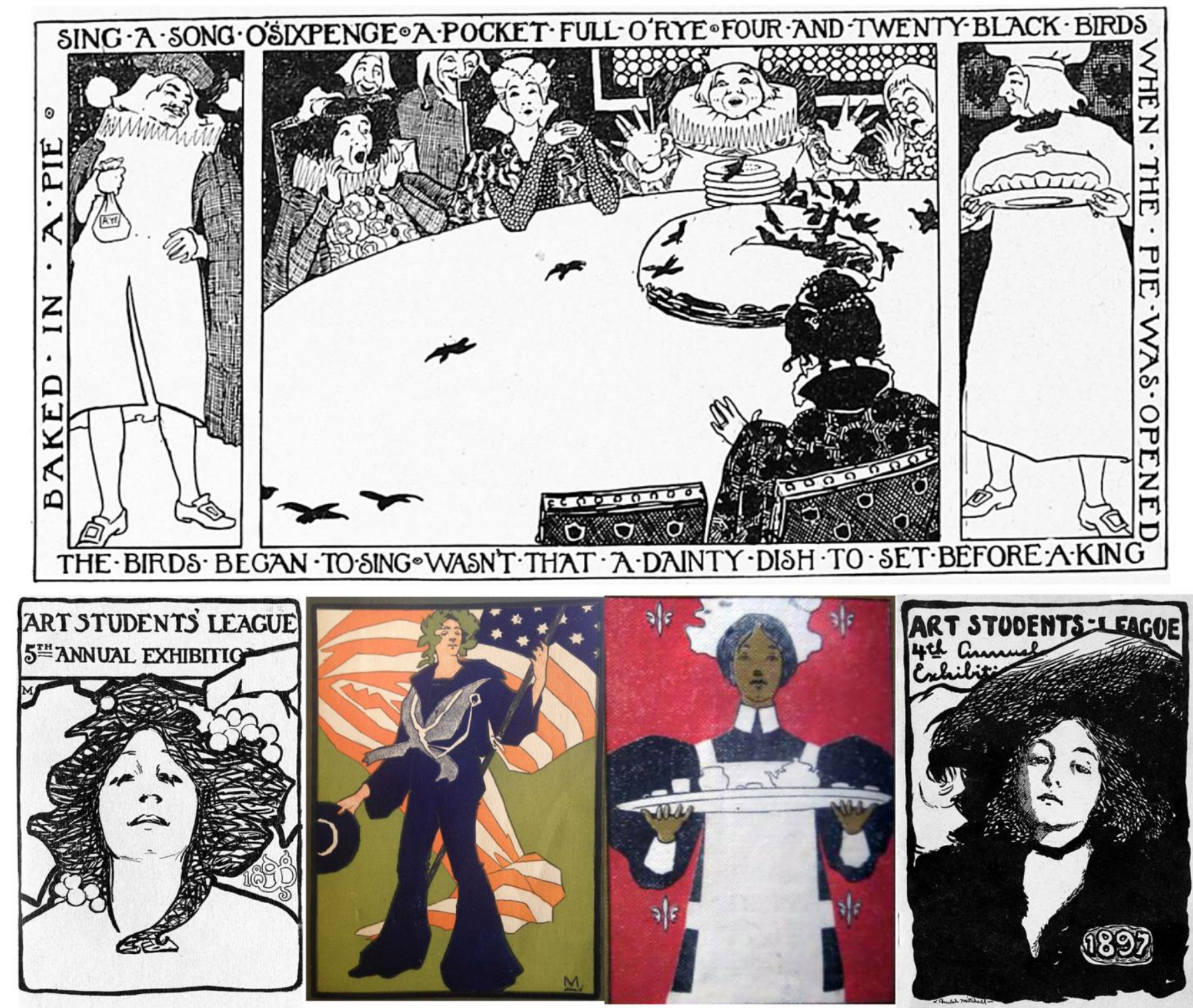

Fig. 1. Some examples of Beulah Clute's work as a student of the Art Institute of Chicago from 1895 to 1899 (age 22-27 years). The top panel, The Mother Goose Tale, was featured in an 1898 article on the illustration class of the Art Institute of Chicago. The bottom panel, from right to left: the cover illustration of the catalogue of the Art Students League 1897 exhibition, the cover illustration of the 1896 Chicago Record

Cookbook, the cover illustration of the November 1998 issue of Pickwick Magazine, and the cover illustration of the catalogue of the 1898 Art Students League Exhibition.

\section{The Bookplates of L. Beulah Mitchell 1898-1900}

Beulah Mitchell's early bookplates are easily distinguished from her later bookplates as she signed them 'LBM'. The first bookplates known appear to be two she exhibited in in the 1898 exhibition of the Students Art League: "Design for bookplate, loaned by Miss Lyon" and "Design for book plate, loaned by Mr. Leaming". The Lyon bookplate was for Florence L. Lyon, a friend of the Mitchell family in Decatur who like Beulah was in studying in Chicago. These and other bookplates produced during her student days are shown in figure 2 . They encompass a very wide range of styles. Some were made for people with whom we know she had a personal tie or connection such as her soon to be fiancé Walter Clute, a fellow art student at the Art Institute of Chicago Grace C. Hendricks, her uncle George F. Seely who was a successful Chicago businessman, and the reknowned New York painter Charles F. Von Saltza who lectured occasionally at the Art Institute of Chicago. Other the 9 shown in fig. 2, Beulah Mitchell is said to have designed a bookplate for the Chicago painter John Vanderpoel, a famous painter and instructor 
at the Art Institute of Chicago (Anon. 1900) but no illustration of his bookplate was found. In total documentation exists for 10 bookplates from the student days of Beulah Mitchell. She apparently began working on bookplates while a student in New York.

In later years she was interviewed for an article in the Book-Plate Booklet (Anon. 1911a) and said that she was often asked how she came to be a bookplate designer and would answer:

"It was my third year at the Art Students League of New York where the routine academic work of the school provided little exercise for the imagination as there was no composition class-nothing, in fact, in which the student was allowed to employ his constructive facility in picture making."

"From the first I felt the academic to be but a means to the end and my own method of expression (swinging more and more to pure line adapted to decorative treatment of figure and landscape) was demanding some definite work. One day a friend came to me saying: 'I have found for you a line of art work wherein you may use all of your skill and imagination, and it is well-suited to your mode of expression. ' and so I received my first commission for a book-plate-without pay!" 

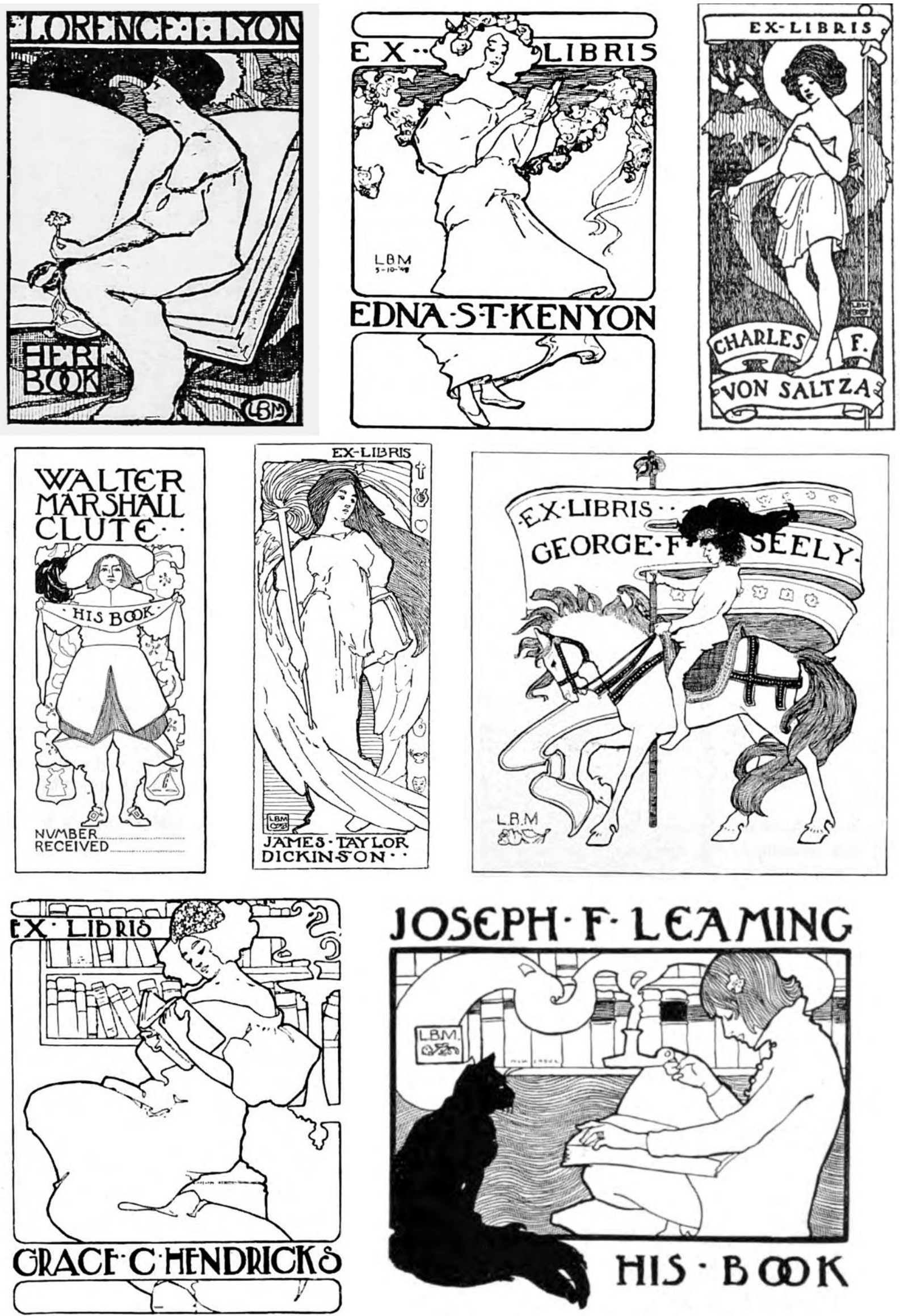

Fig. 2. Beulah Clute early bookplates made during her years as a student at the Chicago Art Institute (1886-1889). Note that all of the bookplates are largely decorative with none depicting any special interests or accomplishments. 
The bookplates signed LBM, created before her marriage, under the name L. Beulah Mitchell, established her reputation as a talented designer. In Bowdoin's book on the history of bookplates, The Rise of the Bookplate, a Miss Beulah Mitchell is found among the list of "Some of the More Important Recent American Engravers and Designers of Book-Plates". The bookplates of Edna ST Kenyon and Charles Von Saltza (fig. 2) were featured in an article in The Pebble (anon. 1900). The Edna ST Kenyon bookplate was also shown in article "Some bookplates and their advertising lesson" in The American Printer (Anon. 1901b) and in "Recent American Ex Libris" in the Cornhill Booklet (Stone 1901).

\section{The Bookplates of Beulah Mitchell Clute 1900-1915}

The period of 1900-1915 was framed between her marriage to Walter Clute and her move to Berkeley after his death in 1915. It corresponds to the period when she had a young child to raise and was working in the 'Colony Craft' workshop in Park Ridge producing not only bookplates but also postcards and holiday cards. Thirteen bookplates of Beulah Clute (fig. 3, 4) are known from the period between 1900 and 1915. There are likely other bookplates but they are today are undocumented. As mentioned above, she exhibited 12 bookplate designs in the 1907 exhibition and 12 prints, presumably bookplates, and in the 1911 exhibition of the Chicago Art Institute (Anon. 1911b) but which we do not know the identities of the bookplates.

Some of the bookplates from this period received a considerable amount of attention. Beulah Clute exhibited the bookplate of the Mitchell children Marjory and Percival (fig. 3) in a 1901 exhibition in Philadelphia (Anon. 1901C) and it was was shown by Zella Dixson, a prolific writer on bookplates, in her 1902 article, Children's Bookplates in the magazine Outlook (Dixson 1902) and described in her 1903 book "Concerning Book-plates" (Dixson 1903). Wilbur Stone, another prolific writer on bookplates, also showed the bookplate of the Mitchell children in his article, Book-plates for Children in St. Nicolas Magazine (Stone 1902) and the bookplate of the Mitchell parents (fig. 4) was shown in Stone's 1902 book "Women Designers of Book-Plates" (Stone 1902). Stone's book was reviewed very favorably in the New York Times and the review noted "In our country, Mrs. Beulah Clute has an enviable reputation as a book plate designer." (Anon 1902). Beulah Clute's bookplate for Joseph Benjamin Oakleaf (fig. 4), who was an ardent collector of the memorabilia of Abraham Lincoln and writer on him, was the subject of a short article in a Moline newspaper (Anon. 1911c). The bookplate is described in the article as designed by Mrs. Beulah Clute, on suggestions given by Oakleaf. It is the first known of her bookplates to very prominently show the interest or expertise of the bookplate owner, in this case Oakleaf's interest and expertise concerning Abraham Lincoln. It differed in overall design, resembling an altarpiece, from her previous bookplates. Two other bookplates from this period were the decorative ones of Mary Augusta Wilson and Bessie Virginia Allen (fig. 4), both shown in an article by Cheney (1914) "Garden Book-Pates" in the magazine American Homes and Gardens. 

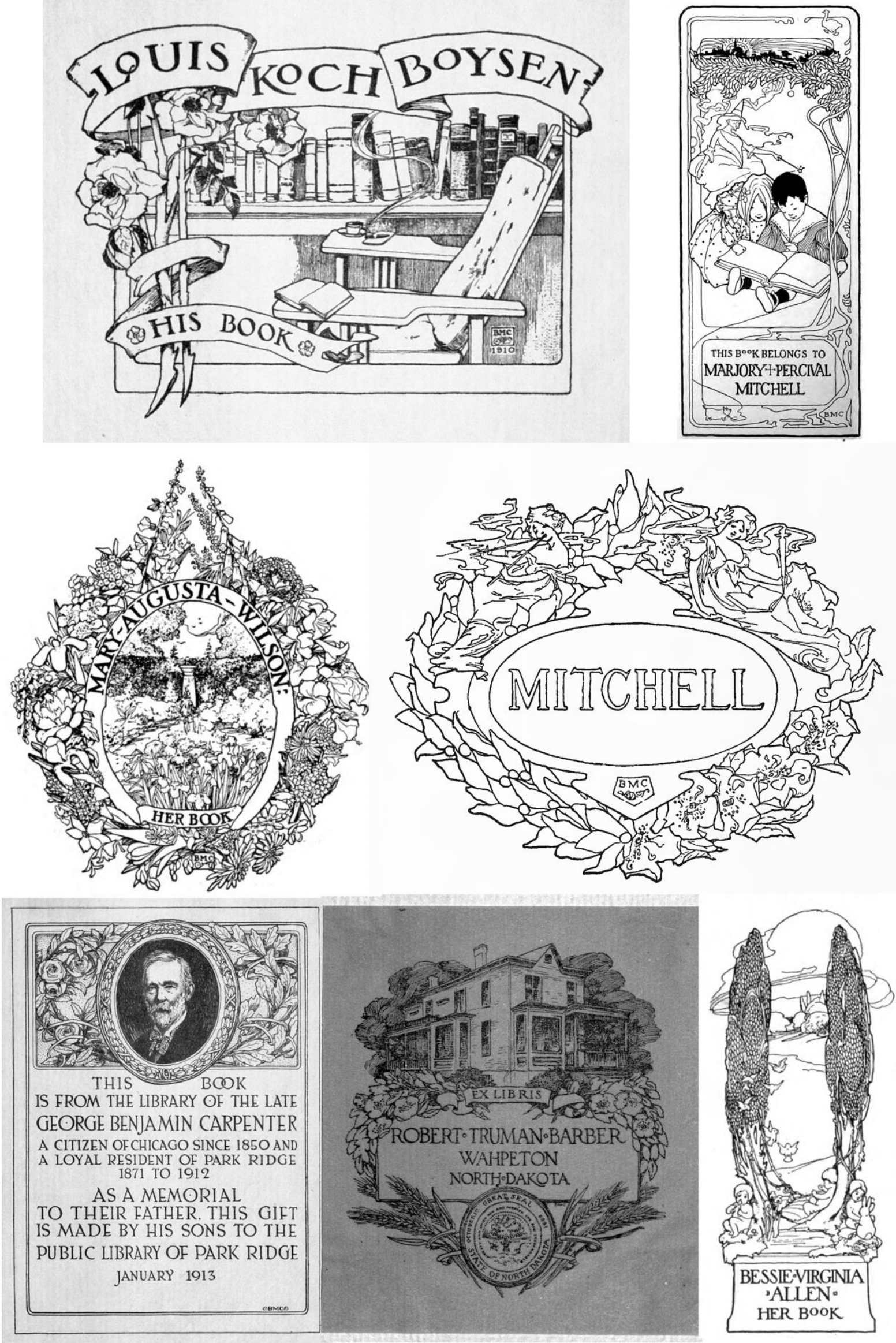

Fig. 3. Seven of the 13 known bookplates of Beulah Clute made during the period of 1900 to 1915, after her marriage to Walter Clute and before her arrival in Berkeley. 

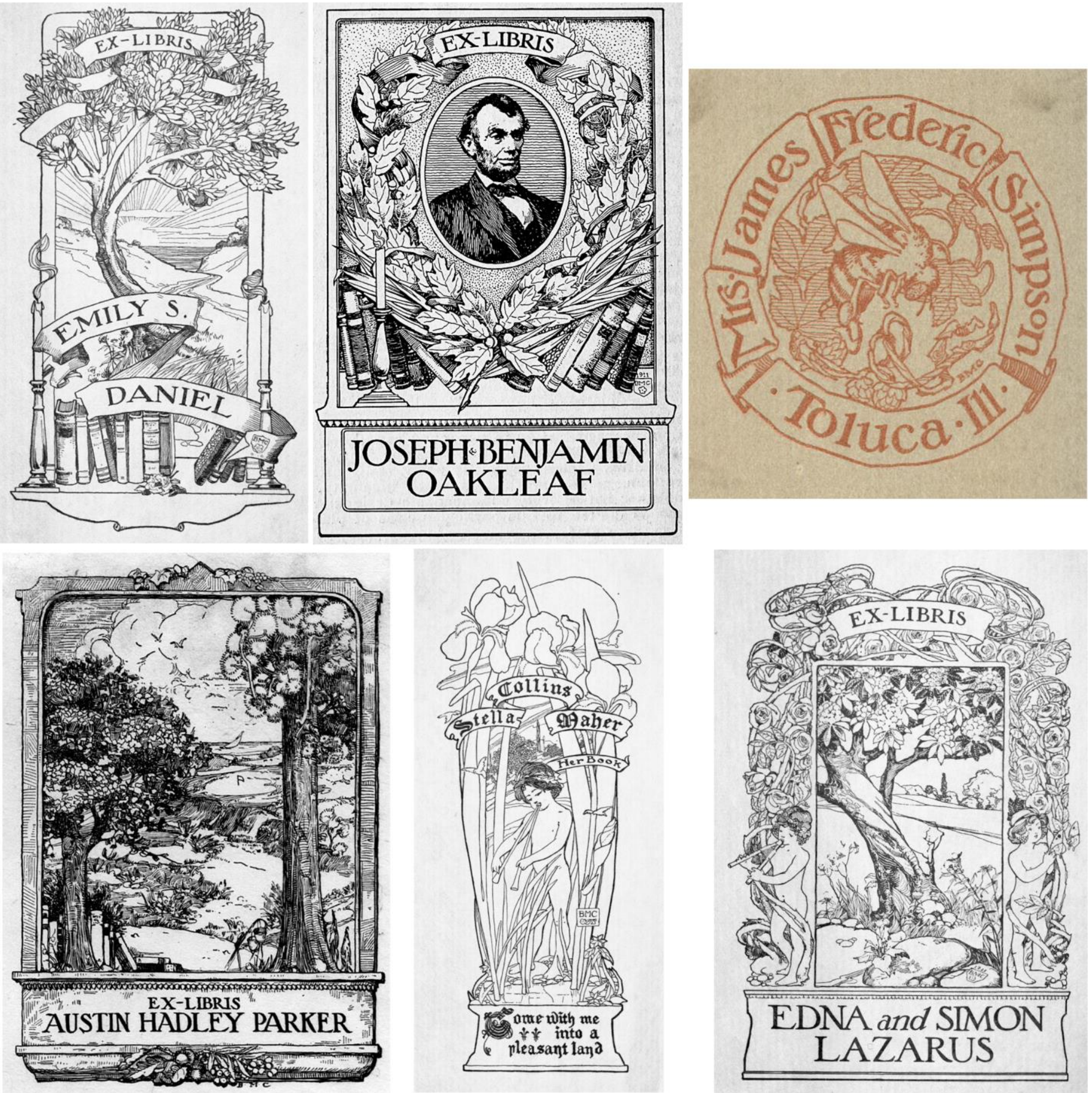

Fig. 4. Six of the 13 known bookplates of Beulah Clute known, from the period of 1900 to 1915, after her marriage to Walter Clute and before her arrival in Berkeley.

\section{The Berkeley Period of Beulah Clute}

Shortly after her husband's death Beulah Clute moved with her daughter to Berkeley, joining her younger sister Eunice, who was married to the mathematician Norman Lehmer. In Berkeley, Beulah Clute quickly let it be known that she was an illustrator and designer of bookplates looking for work. In late 1915, she ran advertisements in the magazine The Miscellany and contributed a cover illustration to the magazine as well; by 1921 she was the designer for the Three Redwoods Studio in Berkeley (fig. 5) 

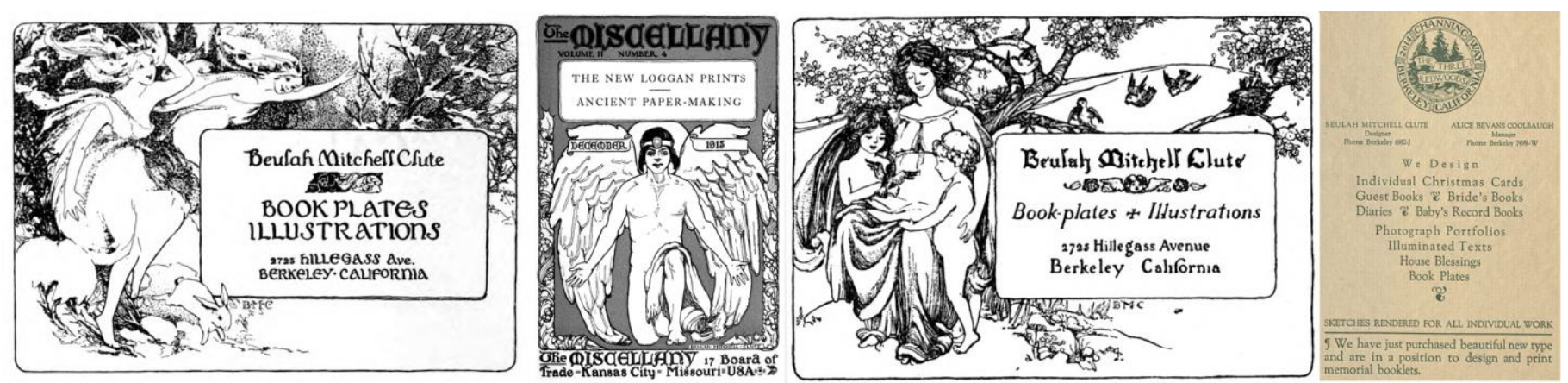

Fig. 5. Beulah Clute, the single mother, in 1915 advertised her services as a bookplate designer and illustrator in the bookplate magazine Miscellany. She also did the cover illustration of the December issue. Note that the style of the cover illustration differed considerably from the advertisements and her relatively well-known previous work, perhaps to show her versatility. By 1921 she was the designer of the Three Redwoods Studio.

\section{The Leuschner bookplate}

The first bookplate by Beulah Clute known from her Berkeley period, and the first of the three known for scientists of University of California at Berkeley (UCB), was for Armin Otto Leuschner (1868-1953), professor of Astronomy. Leuschner began his career at UCB in 1890 not as an astronomer, but as a mathematician. From 1890 to 1892 he was a math instructor, as was Beulah Clute's brother in-law, Norman Lehmer, at that time. It would seem likely that Lehmer and Leuschner were at least acquaintances and perhaps friends when Beulah Clute arrived in Berkeley in 1915. We know that the Leuschner bookplate dates from 1916 and that she was proud of it as she exhibited it at the 1917 Exhibition of Contemporary Bookplates that restricted entries to bookplates made in 1916 (Anon. 1917).

It is likely that Beulah Clute would have shown Leuschner, as a prospective bookplate client, a portfolio of her previous work. The layout of Leuschner's bookplate (fig. 6) greatly resembles the altarpiece layout of the Oakleaf bookplate (fig. 4). However, in contrast to the Oakleaf bookplate, Leuschner's bookplate is entirely devoted to his interests and accomplishments. The centerpiece depicts a telescope from the time of Galileo. The seal of Leuschner's undergraduate Alma Mater, the University of Michigan, is shown in the top left over the first part of the motto ad astra (to the stars) and the seal of the University of California where he worked from 1890 until his retirement in 1938 is shown in top right over the second part of the motto per aspera (through difficulties). The medal shown in lower left is the James Craig Watson Medal. It is awarded by the National Academy of Sciences (USA), and was awarded to Leuschner in 1916. It is one of the highest recognitions in astronomy. The seal shown in the lower left is that of the National Academy of Sciences (USA) to which Leuschner was elected in 1913. 

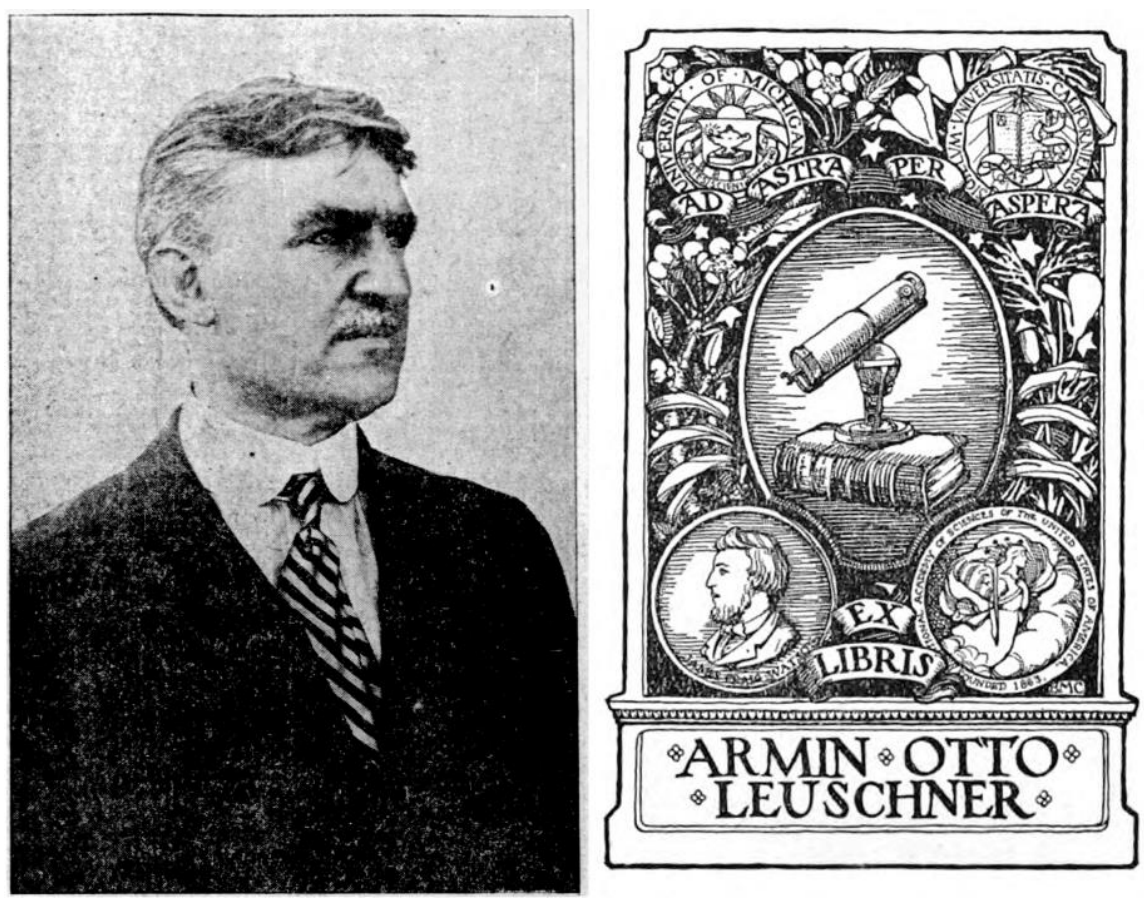

Fig 6. The astronomer Armin Otto Leuschner, from a 1916 newspaper article (anon. 1916), and his and his bookplate. His bookplate showcased his education, field of research, and his award from, and election to, the National Academy of Sciences (USA). At UCB Leuschner was Professor of Astronomy, chairman of the Department of Astronomy from 1900 to1938, and Dean of the Graduate School from 1913 to 1923. In 1913 he was elected to the US National Academy of Sciences (USA) and named a Fellow of the American Association for the Advancement of Science.

\section{The Kofoid bookplate}

The second bookplate for a UCB scientist appears to have been that of Charles Atwood Kofoid (1865-1947). He was a zoologist and his bookplate was adorned with images of the many species of microorganisms he described. A large portion of the bookplate is a scene of a ship at sea pulling a plankton net in the depths of a sea populated by different forms of microorganisms. Of the microscopic forms shown, most are readily recognizable as some of those described in his publications, mostly based on samples he gathered during the 1901 Agassiz Expedition to the South Pacific. Knowledge of his publications allows dating the bookplate, based on the organisms shown, to 1929 or later. The upper portion of the bookplate depicts his study in his home, showing a bookcase and the view of the Campanile Tower of UCB, marking his involvement with the university. He was elected to the National Academy of Sciences (USA) in 1922. Kofoid was named Professor of Zoology in 1910 and was Chairman of the Department of Zoology from 1910 until his retirement in 1936. In a biography of Kofoid (Goldschmidt 1951) it was remarked "He also had the old-fashioned, actually European, idea that the Chairman is the Department and therefore considered all funds and assistance as belonging only to his work, which caused much unhappiness among the other professors." 


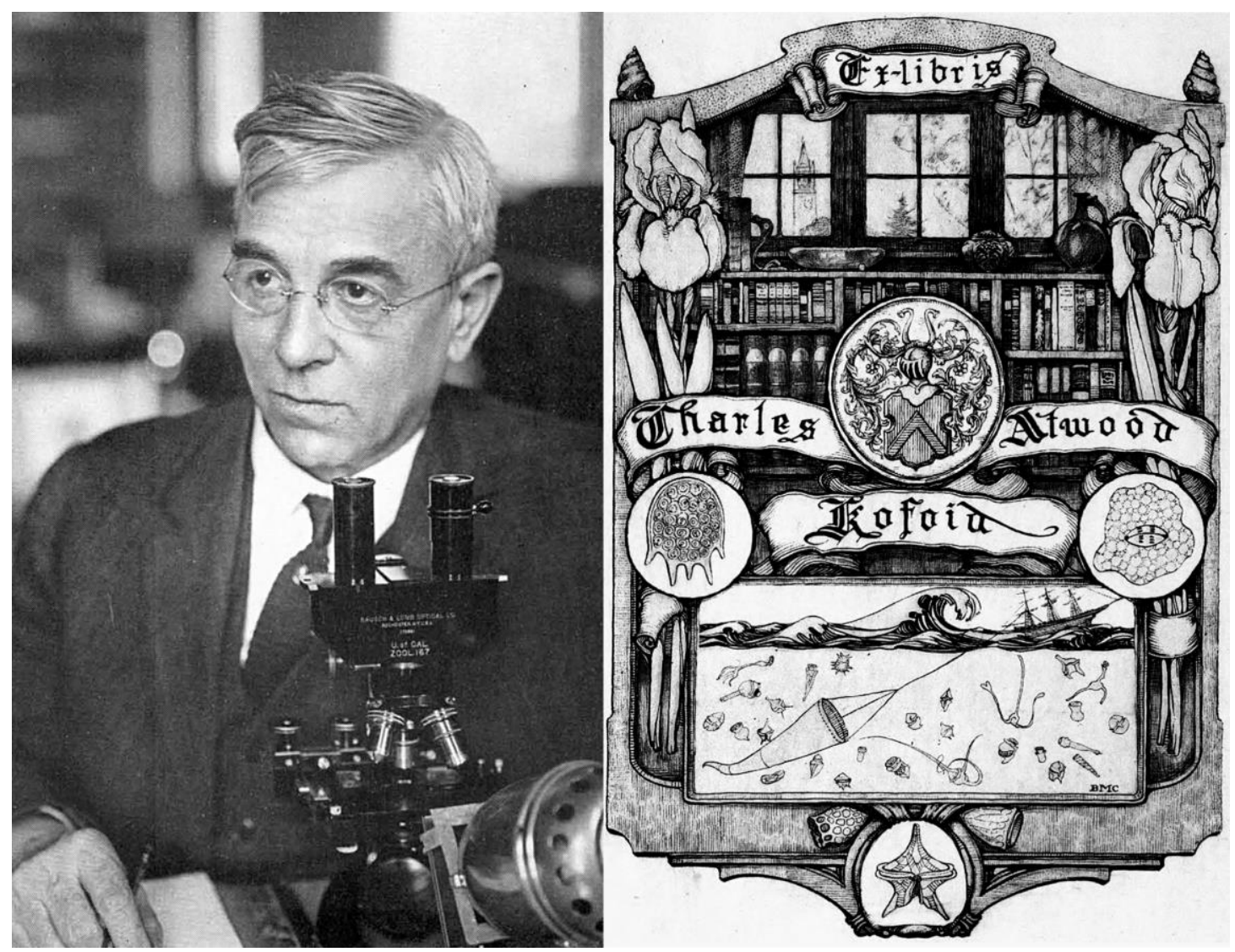

Fig 7. Charles Atwood Kofoid and his bookplate. The image of Kofoid dates from about 1930. The first year his bookplate was mentioned (but not shown) was in Talbot's "Historic California in Book Plates". Kofoid's bookplate depicted his study with it view of UCB and showcased the many different microorganisms he had described and named from the marine plankton in the lower marine scene. Above the scene on the left is

an algae he described and named from his pre-Berkeley days in Illinois in 1899 and on the right is a depiction of cell division in an amoeba from a 1922 publication. The tintinnids shown (conical shells lying on their sides), directly above the star-shaped dinoflagellate at the bottom center, date the plate to post 1929 , when those two tintinnids were first illustrated in a Kofoid publication, the 1929 monographic work with his student Arthur Campbell.

\section{The Essig Bookplate}

The third UCB scientist bookplate was that of the entomologist Edward Oliver Essig (18841964). It is the most narcissistic of the three bookplates for the UCB scientists (fig. 8). The central scene shows him at work. Essig is seated at his desk in his campus office (the UCB campanile is again shown through the office window). He is using a microscope to examine a specimen, with an open specimen box on the desk. Above Essig's desk are his bookcase, and according to a biography of Essig (Michelbacher 1961), his portraits of the early naturalist he admired, such as Linnaeus and Fabricuis. Above the office scene his summer home on Echo Lake, CA is shown. At the left of the office scene is the bell tower of Pomona College, his undergraduate Alma Mater and at the right one of the irises he created, the prize-winning Easter Morn in 1930, as shown in the medal beneath the iris. The lower portion of the bookplate is decorated with the fuchsia he breed and many seals or symbols showing his education (Pomona College and the University of California), as well as the organizations in which he participated: Alpha Gamma Rho agricultural fraternity, Phi Sigma the biological science award society, Sigma Xi the science research honor society, Alpha Zeta the honor society of agriculture and natural resources, and the American Association of Economic Entomologists. Shown also are two honors awarded Essig: his election as a fellow in the American Association for the Advancement of Science in 1915 and his 1932 French award "Chevalier du Merite Agricole". 

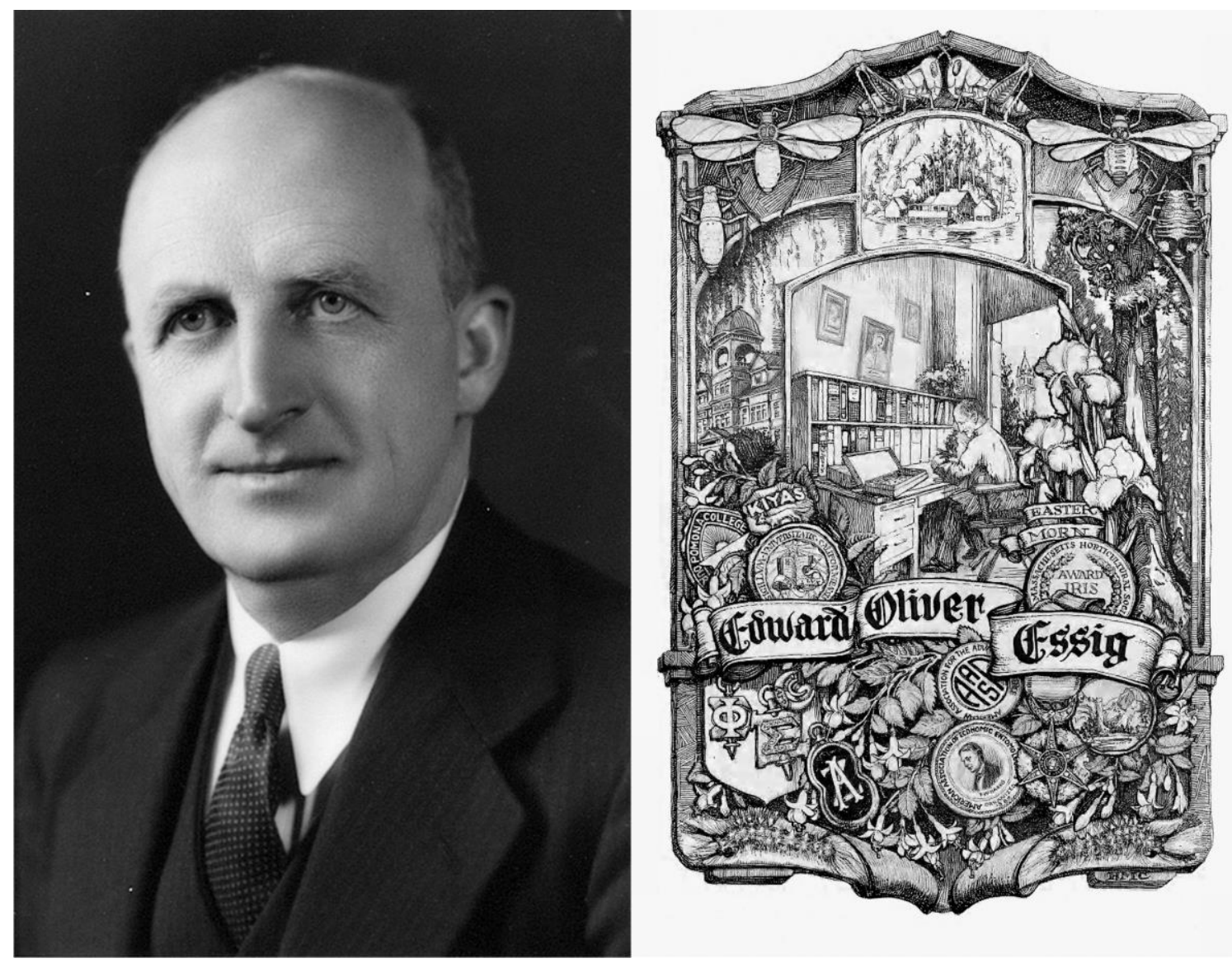

Fig. 8. The entomologist Edward Oliver Essig and his bookplate. The image of Essig dates from about 1936, the first year his bookplate was mentioned. It was first mentioned (but not shown) in Talbot's "Historic

California in Book Plates". The plate shows the Chevalier du Merite Agricole awarded to him in 1932, consequently the plate dates to at least 1932.

Essig joined the Faculty of UCB as an instructor in Entomology in 1914. In 1916 he was named Assistant Professor, in 1921 promoted to Associate Professor and to Professor in 1928. Essig was named "Acting Chair of Entomology" in 1942 and was the Chair of the Department of Entomology and Parasitology from 1943 to 1951. He retired in 1953. With regard to his chairmanship, a biography of Essig (Michelbacher 1961) suggests it was not easily acquired: "Yet his stay at the University was not without its problems, especially in the late nineteen thirties. His dynamic character was not to be submerged by the forces working against him and shortly he was elevated to the chairmanship of the Division of Entomology and Parasitology". The statement suggests that Essig had a strong personality and chairmanship may have been a source of conflict like Kofoid's chairmanship of the Department of Zoology.

\section{Other Clute Bookplates from the Berkeley Period}

There are 18 bookplates known with illustrations (fig. 9, 10, 11) dating from Clute's Berkeley period besides those she created for the UCB scientists. In figure 9, the Dore plate can be dated 1920 as she exhibited it in the 1921 exhibition of contemporary bookplates (Anon. 1921). Three others can be dated as 1923 creations because Beulah Clute exhibited them in a 1924 exhibition: Bade, Frankel, and Legge (Anon. 1924). The 4 bookplates each contain an element identifying an interest or accomplishment. The bookplate of Dore showing a stamp and an album identifies him as a collector of stamps. The bookplate of Bade shows his office at the Pacific School of Religion, where was Dean, and also shows the seal of the school. Bade was then and now very well known as an archeologist of biblical sites and as the editor of the writings of John Muir, the pioneer nature conservationist of the United States. The bookplate of Frankel included the seal of her Alma Mater, Wellesley College. The bookplate of the Legges featured the Caduceus, a symbol of medicine in the 
United States as Robert Legge was a medical doctor and Professor of Hygiene at UCB. Notably, in none of the bookplates were the accomplishments of the book owner the central element, in contrast to those of the UCB scientists. The very decorative bookplate of Martha Barker Alexander was shown by Beulah Clute in her 1924 article. It was for Miss Martha Barker Alexander, (1909-1971). She was the daughter of Wallace M. Alexander, a wealthy San Francisco businessman and president of the San Francisco Chamber of Commerce (Chickering 1939). She was later known as Martha Alexander Gerbode, the wife of D. A. Gebode, the heart surgeon. She was a well-known environmentalist, philanthropist, and volunteer in the San Francisco Bay Area and Hawaii. The bookplate is one of two known in color of Beulah Clute. The other was for Violet V. Collins.

In figure 10, Isabelle Bonnar Faye's bookplate shows the seal of her Alma Mater, Wellesley College (AB degree in 1921) and a view of a Hawaiian landscape. The bookplate of Edwin Letts Oliver (1878-1936) shows a house in a forest and an industrial machine. He was a very wealthy San Francisco mine owner and engineer. The bookplates of Ruth Parker Allen and Barbara Frick appear largely decorative. The bookplate of Editha Webster Johnston shows a 3-masted ship, perhaps the Jeanie Johnston which brought Irish immigrants to Canada, and the seal of the University of Toronto. The ornate and finely detailed bookplate for the John Muir School in Berkeley is a bit of a mystery. It was shown in a 1936 book (Talbot 1936). The school was founded in 1916 as a small, experimental, public elementary school. It was an early Montessori school in which activities and experiences in nature were the focus rather than learning from books. The bookplate shows the Redwood trees John Muir championed and children are shown exploring fields. The creation of a bookplate, a non-trivial expense, for a small public elementary school in which book learning was eschewed is odd. As noted above, Bade was the editor of John Muir's writings. He may have commissioned the bookplate for a school named after his long-term friend. Finally, in figure 11 are shown the largely decorative bookplates of Franklin Porter Nutting, Margaret Magdalene Taylor, Elsie Allen, and Ralph Palmer Merritt and Frederic Mason Blanchard 

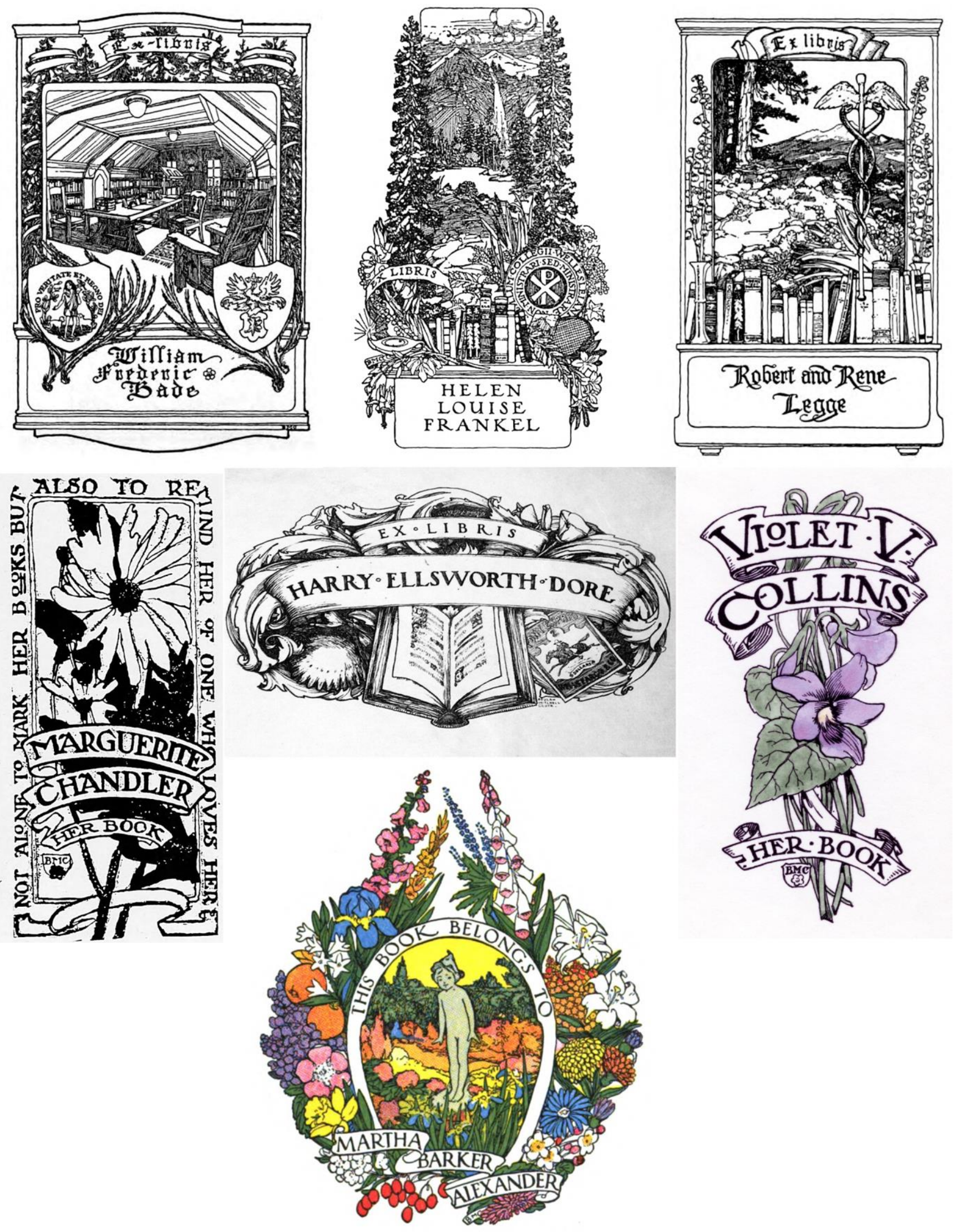

Fig 9. The bookplates known from Clute's Berkeley period (1915-1958) other than those of the UCB scientists, continued in figs 10 and 11. The top 3 can be dated as designed in 1923 (Anon. 1924). The bookplate of William Frederic Badè shows his study at the Pacific School of Religion where he was Dean

The bookplate of Helen Louise Frankel included the seal of her Alma Mater, Wellesley College. The bookplate of Robert and René Legge showed the symbol of Medicine; Robert Legge was a Professor of

Hygiene at UCB. The Harry Ellsworth Dore bookplate, prominently features Dore's interest in stamp collecting. The bookplates of Margaret Chandler, Martha Barker Alexander, and Violet V. Collins are purely 

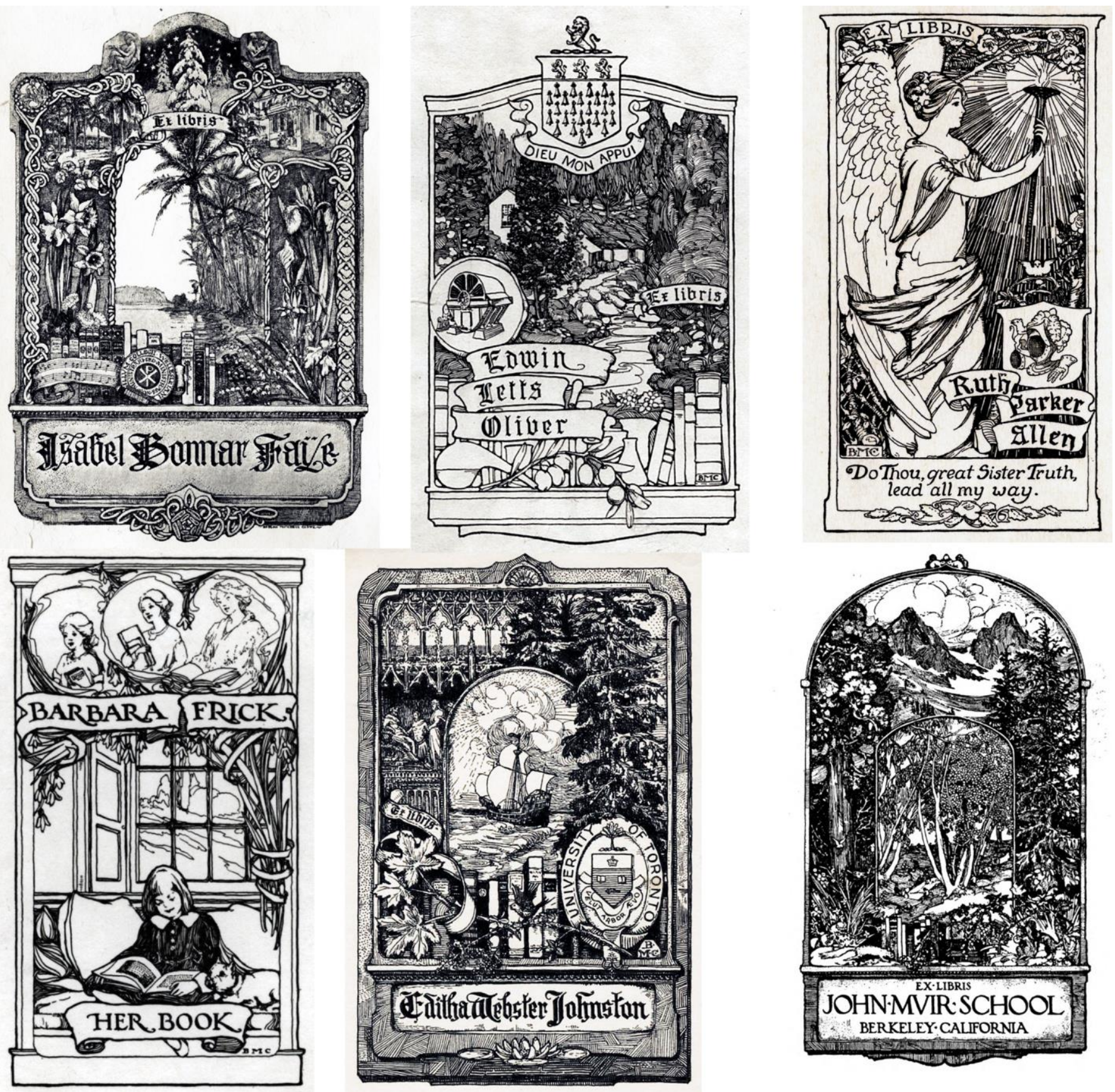

Fig 10. The bookplates known from Clute's Berkeley period (1915-1958) other than those of the UCB scientists continued. Isabelle Bonnar Faye's bookplate shows the seal of her Alma Mater, Wellesley College (AB degree in 1921) and a view of a Hawaiian landscape. The bookplate of Edwin Letts Oliver (1878-1936) shows a house in a forest and an industrial machine. He was a very wealthy San Francisco mine owner and engineer. The bookplates of Ruth Parker Allen and Barbara Frick appear largely decorative. The bookplate of Editha Webster Johnston shows a 3-masted ship, perhaps the Jeanie Johnston which brought Irish immigrants to Canada, and the seal of the University of Toronto. 


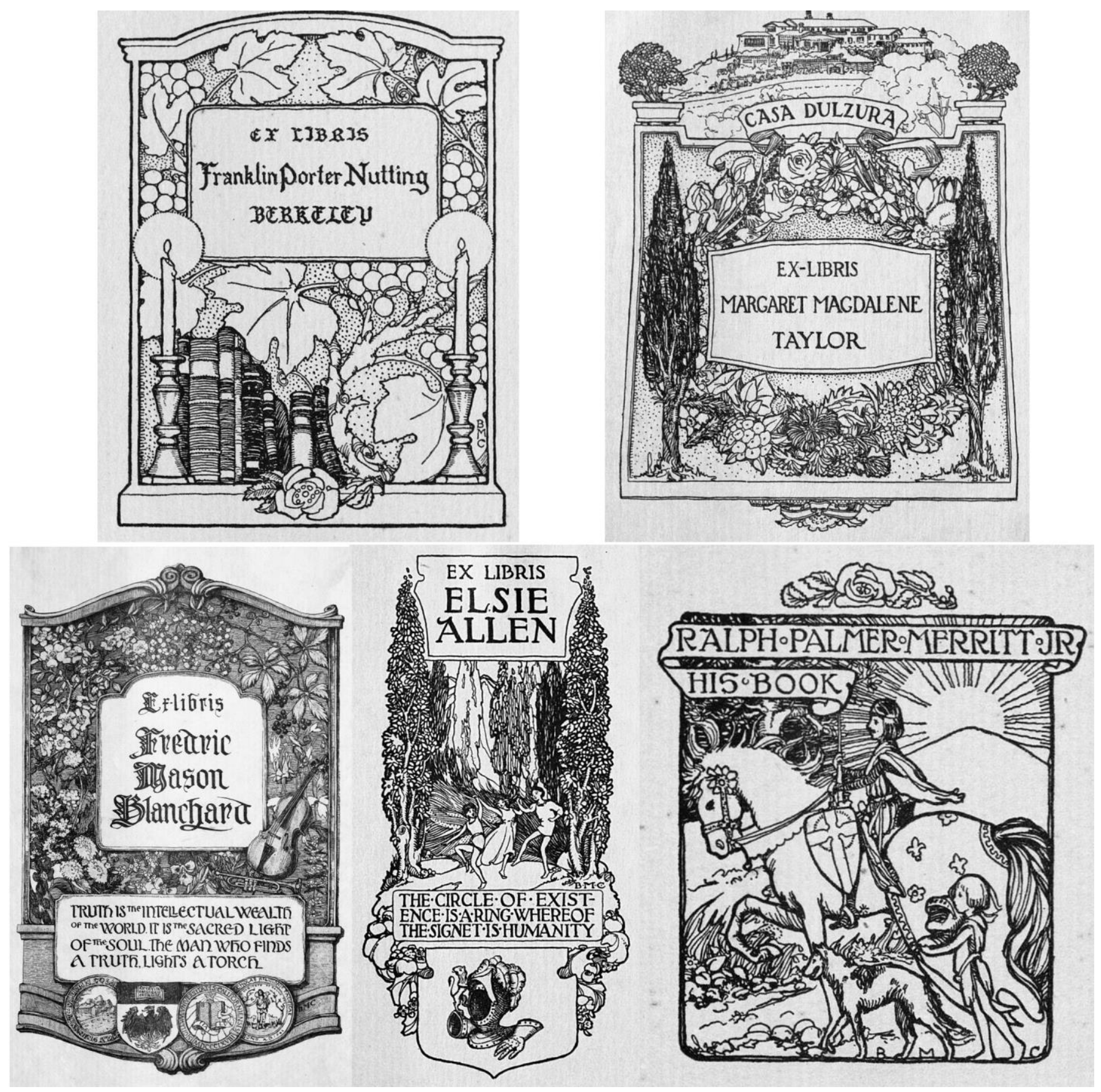

Fig. 11. Bookplates The bookplates known from Clute's Berkeley period (1915-1958) other than those of the UCB scientists continued and end. The bookplates of Franklin Porter Nutting, Margaret Magdalene Taylor, Elsie Allen, and Ralph Palmer Merritt are purely decorative. Frederic Mason Blanchard's bookplate shows the seals of the schools where he taught public speaking, including UCB, and the instrument he played in a Chicago orchestra.

\section{The Peculiarities of the bookplates of the UCB scientists}

I found documentation for a total of 80 Beulah Clute bookplates (a listing with notes is available on request). Shown here are 42 of the bookplates. While not representing all her known bookplate work, the peculiarity of the bookplates of the three UCB scientists is the showcasing of the accomplishments of the scientists. Thus, her work for the UCB scientists stands out from her work for others. One might think that Belulah Clute's other clients were perhaps not particularly accomplished. However, the others included some individuals of very considerable renown such as the painter Charles F. Von Saltza, the Chicago banker Louis Koch Boysen and the Berkeley academics William Frederich Badé, Robert Legge and Frederic Mason Blanchard. These latter three were contemporaries of the UCB scientists. Another person of note was Edwin Letts Oliver, a 
millionaire mining engineer and major figure in San Francisco society (e.g. Parratt 1955). His bookplate showed only rather discretely a machine. Likewise Ralph Palmer Merritt was a regent of UCB, president of the California State Chamber of Commerce as well as the United States Chamber of Commerce and his bookplate was purely decorative. The bookplates of the scientists, in contrast, are dominated by indications of their activities and accomplishments. Obviously, vanity and narcissism are not unique to scientists. However, some attention has been directed toward examining the characters of 'successful scientists'.

Merton (1968) described possession of a 'big ego' as common attribute of Nobel Prize winning scientists and to be well aware of the "Mathew Principle" in regard to scientific reputation, i.e., the richer get richer and the poor get poorer. Narcissism, as a personality trait, not a pathology, has been described as common among powerful scientists in the life sciences with such personalities having an overall negative effect on the quality of science (Lemaitre, 2015, 2017). Such statements are likely not surprising to research scientists. The quest for visibility among scientists in recent years has been bemoaned as having transformed science into an activity not motivated primarily by curiosity, but rather by competition and commercial success (Madesn 2019). However, creativity has also been associated with narcissism (Jauk \& Sordia 2018), so perhaps it is a necessary evil?

It is a great pity that Beulah Mitchell did not write a memoir like her grandmother and sister-inlaw. I for one cannot help but wonder what Beulah Mitchell thought when she designing the bookplates of the UCB scientists. Recall that when she arrived in Berkeley she was bookplate designer of some repute, considered at the time one of the foremost designers (Butler 2000) and had been designing bookplates for over 17 years. When commissioning their bookplates, each man had to have provided her with a pile of sketches of awards, seals, badges, diverse organisms and photographs of the items or scenes they wished to be depicted or thought might be included. I would like to have asked what she thought of the men while designing their bookplates!

\section{Acknowledgements}

I owe much to Anthony Pincott. He provided encouragement and a considerable amount of information with regard to bookplates in general and the bookplates of Beulah Clute in particular. Special Collections, University of Delaware Library, Museums and Press, Newark, Delaware, provided a copy of the 1911 Book-Plate Booklet article. Images of bookplates of the Barbara Abele Bookplate Collection in Box 7, folder 18, were provided by the department of Special Collections and University Archives, San Diego State University Library, San Diego, California. Kirsten MacLeod of Newcastle University kindly provided the image of the cover of Pickwick Magazine.

\section{References}

Anon. 1897a. In Perspective in February. The Sunday Inter Ocean, Feb. 14, 1897, pg. 27.

Anon. 1897b. In the world of art. The Sunday Chronicle, Chicago, Dec. 12, 1897, pg. 44.

Anon. 1897c. Art news. Brush and Pencil, 1:76-78.

Anon. 1898a. Scraps of news. The Decatur Review, Sept. 14, 1898, pg. 8

Anon. 1898b. The School of the Art Institute of Chicago. IV. The class in illustration. Brush and Pencil, 2:120-123.

Anon. 1898c. Art news. The Daily Inter Ocean, Jun. 17, 1898, pg. 6

Anon. 1899. Dance in quaint costumes. The Daily Inter Ocean, Feb. 15, 1899, pg. 5

Anon. 1900. Two western book-plate designers. The Pebble, 2:38-41

Anon. 1901a. Art Students League of Chicago, Catalogue of the Seventh Annual Exhibition. Chicago: The Art Institute of Chicago

Anon. 1901b. Some Bookplates and their advertising lesson. The American Printer, 33:108-109. 
Anon. 1901c. Catalogue of the Seventh Annual Exhibition, January 14 to February 23, 1901. Philadelphia: The Pennsylvania Academy of Fine Arts.

Anon. 1902. Women designers of book-plates. New York Times Saturday Review of Books, July 26, 1902, pg. 509.

Anon. 1907. Catalogue of the Nineteenth Annual Exhibition of Water-Colors, Pastels and Miniatures by American Artists. Chicago: The Art Institute of Chicago

Anon. 1911a Book-plates by Beulah Mitchell Clute. The Book-Plate Booklet, Sept. 1911, pg 38-41. Special Collections, University of Delaware Library, Museums and Press, Newark, Delaware.

Anon. 1911b. Catalogue of the Twenty-Third Annual Exhibition of Water-Colors, Pastels and Miniatures by American Artists. Chicago: The Art Institute of Chicago

Anon. 1911c. Praises Oakleaf book-plate. Moline Daily Dispatch, Sept. 25, 1911, pg. 2.

Anon. 1917. The second annual exhibition of contemporary bookplates. The Bookplate Booklet, 1, unpaginated.

Anon. 1921. The sixth annual exhibition of contemporary bookplates. The Bookplate Annual for 1921, Fowler, A. (ed), Kansas City: Alfred Fowler, pp 26-29.

Anon. 1924. The ninth annual exhibition of contemporary bookplates. The Bookplate Chronicle, 2:21-27.

Anon. 2011. A gift for the ages. Fiat Lux, Fall 2011, n 21: 1-4

Baker, M.S. 1899. The Art Students League. Brush and Pencil, 3:235-238.

Barnes, D. 2010. Park Ridge. Charleston (SC): Arcadia Publishing

Bowdoin, W.G. 1901. The Rise of the Book-Plate. New York: A. Wessels Company

Bowdoin, W.G. 1917. Some notes on book-plates and on collecting them. The Brookyln Museum Quarterly, 4: 211220.

Butler, W.E. 2000. American Bookplates. London: Primrose Hill Press, Ltd.

Chickering, A.L. 1939. Wallace M. Alexander, 1869-1939. California Historical Society Quarterly, 18:379-381.

Clute, B.M. 1924. The Bookplate. University of California Chronicle, 26: 147-159.

Dixson, Z.A. 1902. Childrens book-plates. The Outlook, 72:812-1816.

Dixson, Z.A. 1903. Concerning Book-Plates, a Handbook for Collectors. Chicago: Wisteria Cottage Press

Goldschmidt, R.B. 1951. Charles Atwood Kofoid 1865-1947, a Biographical Memoir. Washington D.C: National Academy of Sciences.

Jackson, I. 2003. Charles Atwood Kofoid and scientific book -collecting at Berekely. The Bookplate Journal, 1:39-44.

Lehmer, D.H. 1943. Just the Two of Us: Verses for Boys and Girls. Berkeley: The Gillick Press

Michelbacher 1961. Edward Oliver Essig 1884-1964. The Pan-Pacific Entomologist, 41:207-234.

Mitchell, L. S. 1953. Two Lives, The Story of Wesley Clair Mitchell and Myself. New York: Simon and Schuster.

Parratt, E.M. 1955. Edwin Letts Oliver. California Historical Society Quarterly, 34:374-375.

Sanders, K. 2011. My Bucket's got a hole in it: a tale of brine shrimp, the lost Kofoid books and a happy ending for the Berkeley library. Bancroftiana ${ }^{\circ}$ 139:14-15.

Seeley, B.M. 1901. A Story of My Life. Berkeley: privately published

Stone, W.M. 1901. Recent American Ex Libris. The Cornhill Booklet, 2:43-54.

Stone, W.M. 1902. Women Designers of Book-Plates. New York: Randolph R. Beam.

Talbot, C.R. 1936. Historic California in Bookplates. Los Angeles: Graphic Press. 